\title{
Chemical characterization of archaeological pottery of the Lower Paraná River
}

\section{(Caracterização química da cerâmica arqueológica do Baixo Rio Paraná)}

\author{
D. Loponte ${ }^{* 1}$, J. Morales ${ }^{2}$, A. Gogichaishvili ${ }^{2}$, A. Acosta $^{1}$ \\ ${ }^{1}$ Instituto Nacional de Antropología y Pensamiento Latinoamericano, Consejo Nacional de Investigaciones \\ Científicas y Técnicas, 3 de Febrero 1378, Buenos Aires, Argentina \\ ${ }^{2}$ Universidad Nacional Autónoma de México, Unidad Michoacán del Instituto de Geofísica, Laboratorio \\ Universitario de Geofísica Ambiental, Mexico
}

\begin{abstract}
This paper analyzed the chemical composition of archaeological pottery produced by hunter-gatherers and horticulturist populations of the late Holocene of the lower Paraná basin. An energy dispersive X-ray fluorescence spectrometer was used to analyze the chemical composition of the sherds. The results obtained indicated that the analyzed samples, within certain parameters, showed some variability. The differences were even more significant when comparing the chemical composition of the pottery of the huntergatherer groups and that of the horticulturists. The main components identified in the archaeological pottery were grouped primarily with the location of production, that is, they were the result of local manufacturing. Within the trace-elements, the greatest variations in composition were observed in the strontium, which was assumed to vary in concentration levels throughout the region.
\end{abstract}

Keywords: archaeometry, Paraná Basin, pottery, EDXRF, chemical analysis.

\section{Resumo}

Este artigo analisou a composição mineralógica da cerâmica arqueológica produzida por populações de caçadores-coletores e horticultores do Holoceno tardio na parte baixa da bacia do Paraná. Para analisar a composição química dos fragmentos foi utilizado um espectrômetro de fluorescência de raios $X$ de energia dispersiva. Os resultados obtidos indicaram que as amostras analisadas, dentro de certos parâmetros, apresentaram alguma variabilidade. As diferenças foram ainda mais significativas quando se compararam a composição química da cerâmica dos grupos caçadores-coletores com a dos horticultores. Os componentes principais identificados nas cerâmicas arqueológicas foram agrupados de acordo com o local de produção, isto é, resultaram de confecção local. Quanto aos elementos-traço, a maior variação foi relacionada ao estrôncio, que foi assumido variar em níveis de concentração em toda a região.

Palavras-chave: arqueometria, Bacia do Paraná, cerâmica, EDXRF, análise química.

\section{INTRODUCTION}

The X-ray fluorescence (XRF) spectroscopy is currently applied in archaeometry to analyze the chemical composition and the provenance of the pottery, helping to classify them into clusters. These studies are also frequent to recognize the existence of an allochthonous origin of different types of artifacts, mainly made of ceramics, glass and obsidian [1-7]. Until today, they have not yet been applied in the lower Paraná River basin (Fig. 1), where pottery is the most abundant archaeological finding in the sites generated by the pre-Columbian populations between 2.5 and $0.5 \mathrm{ky}$ BP. These societies were complex hunter-gatherer who produced large amounts of pottery in order to cook the foods and to expand the nutrient extraction by boiling. Their subsistence was based on hunting, fishing and gathering of

*dashtown@gmail.com

(D) https://orcid.org/0000-0002-3826-5595 wild vegetables, with occasional ancillary horticulture $[8$, 9]. Its archaeological record has been divided into different clusters, based on the stylistic and typological differences in pottery, ornamental objects and subsistence strategies $[8,9]$. The region was also occupied by Amazonian horticulturists who colonized the area a few centuries before the Spanish conquest. In historical terms, they are known under the Guaraní exonym [10]. They had a mixed economy, including maize horticulture, which in this region appears as the main cultivated plant within these groups. While the first population had simple pottery vessels, consisting basically of bowls of low volumetric capacity, the latter ones developed a sophisticated and complex ceramic equipment, which included large containers of utilitarian pottery for cooking, service and to store food (Figs. 2 and 3). The analyses of thin sections of the pottery of both populations showed significant discontinuities in the preparation of the fabrics, basically because the horticulturists (clustered in the Guaraní archaeological unit) used a large quantity of 
grog and lithic tempers of variable sizes, which are related to the need to elaborate the large vessels typical of the Guaraní pottery $[10,11]$. This study constitutes the first step to characterize the chemical composition of the local archaeological pottery, based on the analysis of energy dispersive X-ray fluorescence (EDXRF). In addition, we seek to answer three basic questions. The first is to know if there was variability in the selectivity and preparation of the fabrics within the hunter-gatherer groups. Second, if these fabrics differ with respect to that used by the horticulturist populations; and third, if we can detect within the analyzed samples evidence of pottery produced in other areas of the wetland or with extra-regional origin.
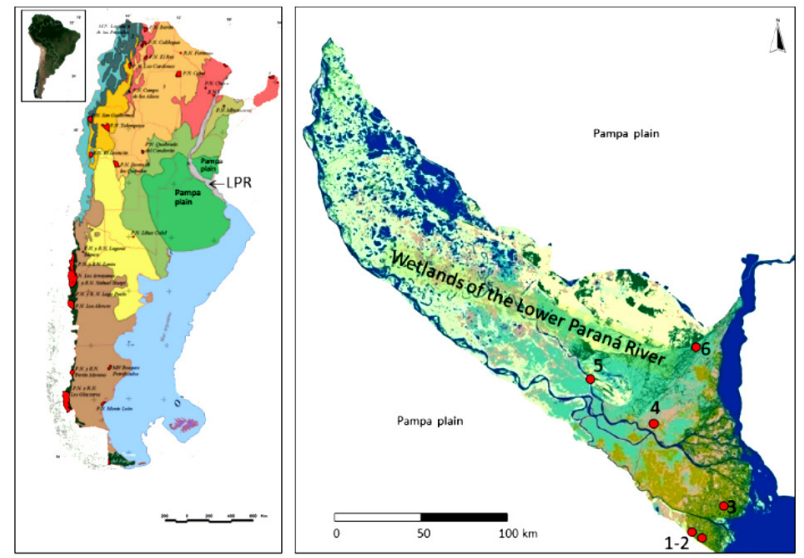

Figure 1: Location of the wetlands of the Lower Paraná River and the studied areas: site 1 and 2 Médanos de Escobar and Anahí; site 3 Arroyo Fredes; site 4 Escuela 31; site 5 La Argentina; site 6 Cerro Mayor.

[Figura 1: Localização do pantanal do Baixo Rio Paraná e áreas de estudo: sítios 1 e 2 Médanos de Escobar e Anahí; sítio 3 Arroyo Fredes; sítio 4 Escuela 31; sítio 5 La Argentina; sítio 6 Cerro Mayor.]

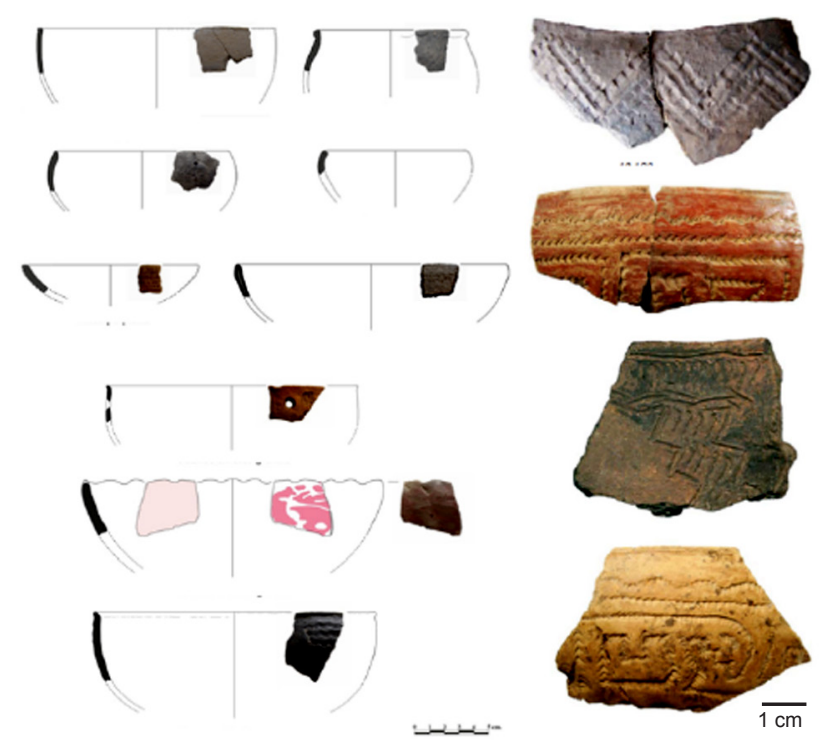

Figure 2: Reconstructed forms of the vessel types recovered at hunter-gatherer sites in the Lower Paraná River.

[Figura 2: Formas reconstruídas dos tipos de vasos recuperados em sítios de caçadores-coletores no Baixo Rio Paraná.]

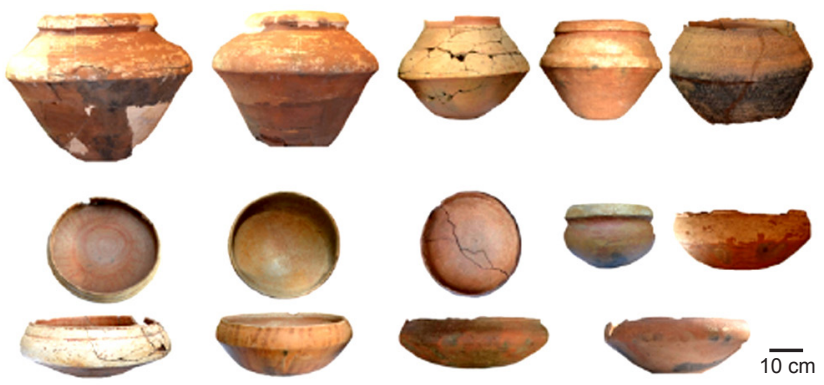

Figure 3: Guaraní pottery from Misiones province.

[Figura 3: Vasilhas guaranis da província de Misiones.]

\section{MATERIALS AND METHODS}

For this study, ordinary, average, unpainted and plain sherds were selected. They were washed by strong brushing and then in an ultrasound tank for total cleaning of sedimentary aggregates from the soil matrices from which they were recovered. Then, they were crashed and pulverized using an agate mortar. $3.3 \mathrm{~g}$ of the obtained powder were weighted and mixed with $0.5 \mathrm{~g}$ of Hoechst wax-c micropowder within the mortar. The mix was placed into a one-inch diameter die and pressed up to 20 ton. The press was allowed to relax for $1 \mathrm{~min}$ and then the pressure was increased again to 20 ton. The system was released and the pressed pellets liberated from the die. All possible precautions were followed to minimize any cross-contamination between samples; these included meticulously cleaning of all the grinding and homogenization equipment with compressedair, distilled water and alcohol to remove any remains from the previously crushed sample. Samples were analyzed using a Xenemetrix's X-Calibur energy dispersive X-ray fluorescence (EDXRF) spectrometer, where 25 lectures of different sherds were obtained. IGL sample series (a set of eight geochemical reference materials) were used for calibration purposes [12]. Analysis of the major and traceelements was carried out in five stages, according to the corresponding interfering elements. Within each run of 7

Table I - Provenance of the samples analyzed. Sites with more than one radiocarbon date are expressed as a maximum/ minimum range.

[Tabela I - Proveniência das amostras analisadas. Sítios com mais de uma data de radiocarbono são expressos como um intervalo máximo/mínimo.]

\begin{tabular}{ccc}
\hline Site & ${ }^{14}$ C years BP & Cluster \\
\hline Arroyo Fredes & $690 \pm 70 / 370 \pm 50$ & Guaraní \\
Anahí & $1020 \pm 70$ & Incised pottery \\
Médanos de & $1752 \pm 33$ & Incised pottery \\
Escobar & & \\
La Argentina & $1645 \pm 34 / 979 \pm 44$ & Incised pottery \\
Cerro Mayor & $1665 \pm 45 / 1561 \pm 45$ & Plain pottery \\
Escuela 31 & $1807 \pm 47 / 1712 \pm 47$ & Goya-Malabrigo \\
\hline
\end{tabular}


samples, a standard was inserted as a reference sample. An integration time of $240 \mathrm{~s}$ was used for all determinations. Pottery sherds used in this study were recovered from five sites of hunter-gatherers and one site of Amazonian horticulturists (Table I). The time span covered by the samples was around 1500 radiocarbon years. Only utilitarian pottery was used to run the analysis, which was determined by the presence of charcoal in the external surface of the sherds. The colors of all cross-sections showed a light brown to a reddish one in the external section due to the oxidizing atmosphere with the presence of $\mathrm{Fe}^{3+}$, and black in the core caused by a reducing condition and incomplete firing. To analyze the results, measures of central tendency, variability and multivariate analysis were applied.

\section{RESULTS AND DISCUSSION}

The results of the semiquantitative analysis of the major

Table II - Chemical composition (wt\%) of the sherds analyzed. X - arithmetic mean; SD - standard deviation; $\mathrm{CV}$ - coefficient of variation.

[Tabela II - Composição química (\% em massa) dos fragmentos analisados. X - média aritmética; SD desvio padrão; $C V$ - coeficiente de variação.]

\begin{tabular}{|c|c|c|c|c|c|c|c|c|c|c|c|}
\hline Sample & $\mathrm{SiO}_{2}$ & $\mathrm{Al}_{2} \mathrm{O}_{3}$ & $\mathrm{Fe}_{2} \mathrm{O}_{3}$ & $\mathrm{MgO}$ & $\mathrm{Na}_{2} \mathrm{O}$ & $\mathrm{P}_{2} \mathrm{O}_{5}$ & $\mathrm{MnO}$ & $\mathrm{CaO}$ & $\mathrm{K}_{2} \mathrm{O}$ & $\mathrm{TiO}_{2}$ & $\Sigma$ \\
\hline \multicolumn{12}{|c|}{ Arroyo Fredes } \\
\hline 234001 & 56.2 & 16.9 & 13.0 & 3.1 & 0.0 & 0.5 & 0.1 & 2.1 & 3.8 & 0.5 & 96.2 \\
\hline 234002 & 55.6 & 16.7 & 14.1 & 2.5 & 0.0 & 1.3 & 0.1 & 2.0 & 3.5 & 0.5 & 96.4 \\
\hline 234003 & 49.0 & 14.5 & 15.4 & 2.9 & 9.4 & 2.0 & 0.1 & 2.6 & 2.2 & 1.8 & 100.0 \\
\hline 234004 & 53.6 & 15.6 & 14.2 & 1.3 & 0.0 & 1.4 & 0.1 & 2.0 & 1.3 & 2.1 & 91.5 \\
\hline 234005 & 51.0 & 16.5 & 15.5 & 3.9 & 0.0 & 1.5 & 0.1 & 1.7 & 3.6 & 0.5 & 94.3 \\
\hline 234006 & 53.6 & 16.6 & 13.6 & 2.9 & 0.0 & 3.3 & 0.1 & 2.7 & 3.3 & 0.6 & 96.7 \\
\hline 234007 & 56.3 & 16.2 & 14.1 & 2.5 & 5.3 & 0.4 & 0.2 & 1.6 & 3.0 & 0.6 & 100.0 \\
\hline 234000 & 52.6 & 14.0 & 14.2 & 2.2 & 0.0 & 0.4 & 0.2 & 1.5 & 3.2 & 0.6 & 88.9 \\
\hline $\mathrm{X}$ & 53.5 & 15.9 & 14.3 & 2.7 & 1.8 & 1.4 & 0.12 & 2.0 & 3.0 & 0.9 & \\
\hline SD & 2.6 & 1.1 & 0.9 & 0.8 & 3.6 & 1.0 & 0.03 & 0.5 & 0.9 & 0.6 & \\
\hline $\mathrm{CV}(\%)$ & 4.8 & 6.9 & 5.9 & 28.7 & 194.6 & 72.3 & 28.8 & 22.5 & 28.3 & 72.9 & \\
\hline \multicolumn{12}{|c|}{ Anahí } \\
\hline 236001 & 60.4 & 14.5 & 13.2 & 1.6 & 0.0 & 0.3 & 0.1 & 2.1 & 2.7 & 0.5 & 95.5 \\
\hline 236002 & 53.8 & 16.0 & 13.8 & 2.0 & 0.0 & 0.8 & 0.1 & 3.5 & 2.7 & 0.5 & 93.4 \\
\hline 236003 & 53.7 & 17.6 & 16.6 & 3.4 & 0.0 & 0.3 & 0.5 & 1.4 & 3.6 & 0.4 & 97.8 \\
\hline 236000 & 46.9 & 14.8 & 16.4 & 3.2 & 0.0 & 0.3 & 0.7 & 1.6 & 3.5 & 0.4 & 87.9 \\
\hline $\mathrm{X}$ & 53.7 & 15.7 & 15.0 & 2.6 & 0.0 & 0.4 & 0.4 & 2.2 & 3.2 & 0.47 & \\
\hline SD & 5.5 & 1.4 & 1.8 & 0.9 & & 0.3 & 0.3 & 1.0 & 0.5 & 0.03 & \\
\hline $\mathrm{CV}(\%)$ & 10.3 & 8.9 & 11.6 & 34.4 & & 61.6 & 78.9 & 43.6 & 15.1 & 6.5 & \\
\hline \multicolumn{12}{|c|}{ Médanos de Escobar } \\
\hline 233001 & 48.9 & 15.3 & 16.0 & 3.0 & 0.0 & 5.4 & 0.4 & 2.3 & 3.2 & 0.5 & 94.9 \\
\hline 233002 & 45.6 & 15.5 & 15.8 & 4.7 & 0.0 & 6.9 & 1.2 & 2.7 & 2.9 & 0.6 & 95.9 \\
\hline 233000 & 47.7 & 16.0 & 16.5 & 3.4 & 0.0 & 3.7 & 0.4 & 1.9 & 3.4 & 0.5 & 93.6 \\
\hline $\mathrm{X}$ & 47.4 & 15.6 & 16.1 & 3.7 & 0.0 & 5.3 & 0.7 & 2.3 & 3.2 & 0.51 & \\
\hline SD & 1.7 & 0.4 & 0.4 & 0.9 & & 1.6 & 0.4 & 0.4 & 0.2 & 0.06 & \\
\hline $\mathrm{CV}(\%)$ & 3.6 & 2.4 & 2.2 & 24.0 & & 29.4 & 67.9 & 15.5 & 7.7 & 12.0 & \\
\hline \multicolumn{12}{|c|}{ La Argentina } \\
\hline 232001 & 55.5 & 17.0 & 13.2 & 2.3 & 0.0 & 2.0 & 0.1 & 2.5 & 4.3 & 0.5 & 97.3 \\
\hline 232003 & 61.5 & 14.5 & 10.9 & 2.6 & 0.0 & 3.0 & 0.2 & 3.0 & 4.5 & 0.5 & 100.0 \\
\hline 232000 & 52.5 & 13.7 & 11.4 & 2.2 & 11.3 & 1.8 & 0.1 & 2.2 & 4.5 & 0.4 & 100.0 \\
\hline X & 56.5 & 15.1 & 11.8 & 2.4 & 3.8 & 2.2 & 0.16 & 2.6 & 4.4 & 0.47 & \\
\hline SD & 4.6 & 1.7 & 1.2 & 0.2 & 6.6 & 0.6 & 0.03 & 0.4 & 0.1 & 0.03 & \\
\hline $\mathrm{CV}(\%)$ & 8.1 & 11.4 & 10.4 & 9.2 & 172.9 & 27.8 & 20.5 & 15.3 & 2.2 & 6.7 & \\
\hline \multicolumn{12}{|c|}{ Cerro Mayor } \\
\hline 231002 & 50.0 & 12.8 & 14.5 & 3.4 & 0.0 & 3.6 & 0.2 & 3.4 & 3.6 & 0.4 & 92.0 \\
\hline 231003 & 47.9 & 13.3 & 16.1 & 2.7 & 0.0 & 2.4 & 0.1 & 2.4 & 3.6 & 0.4 & 89.0 \\
\hline 231007 & 55.8 & 12.6 & 12.8 & 2.8 & 0.0 & 3.1 & 0.2 & 3.3 & 3.8 & 0.5 & 94.9 \\
\hline 231000 & 50.7 & 13.5 & 14.9 & 2.6 & 0.0 & 4.5 & 0.1 & 2.3 & 3.2 & 0.5 & 92.3 \\
\hline$X$ & 51.1 & 13.1 & 14.6 & 2.9 & 0.0 & 3.4 & 0.15 & 2.9 & 3.6 & 0.44 & \\
\hline SD & 3.4 & 0.4 & 1.4 & 0.4 & & 0.9 & 0.02 & 0.6 & 0.3 & 0.02 & \\
\hline $\mathrm{CV}(\%)$ & 6.6 & 3.3 & 9.2 & 13.0 & & 26.2 & 15.0 & 20.3 & 7.5 & 5.4 & \\
\hline \multicolumn{12}{|c|}{ Escuela 31} \\
\hline 235001 & 52.1 & 13.6 & 13.7 & 2.3 & 0.0 & 2.0 & 0.2 & 2.8 & 3.6 & 0.5 & 90.8 \\
\hline 235002 & 43.3 & 12.6 & 21.4 & 2.8 & 0.0 & 3.4 & 0.1 & 3.2 & 2.7 & 0.4 & 89.8 \\
\hline 235000 & 52.0 & 13.2 & 13.7 & 2.5 & 0.0 & 2.0 & 0.1 & 2.7 & 3.6 & 0.5 & 90.4 \\
\hline X & 49.2 & 13.2 & 16.3 & 2.5 & 0.0 & 2.5 & 0.13 & 2.9 & 3.3 & 0.46 & \\
\hline $\mathrm{SD}$ & 5.1 & 0.5 & 4.4 & 0.3 & & 0.8 & 0.03 & 0.3 & 0.6 & 0.06 & \\
\hline $\mathrm{CV}(\%)$ & 10.3 & 3.5 & 27.2 & 9.7 & & 32.4 & 19.3 & 8.7 & 16.8 & 13.6 & \\
\hline
\end{tabular}



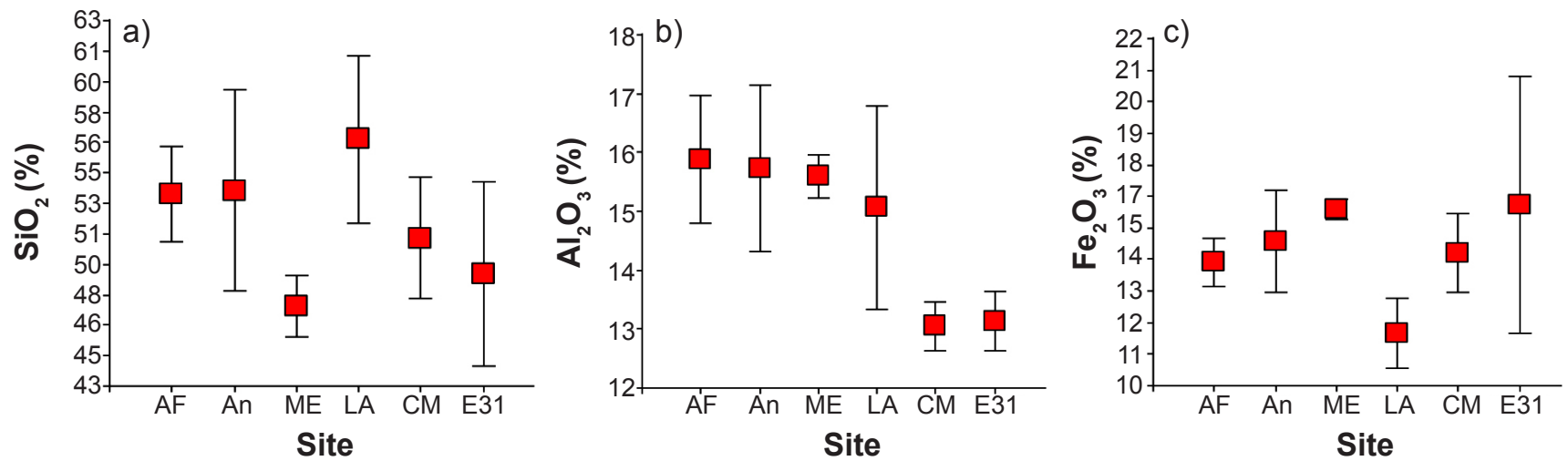

Figure 4: Average values and standard deviation (wt\%) of the three main chemical components of the region's pottery: AF: Arroyo Fredes; An: Anahí; ME: Médanos de Escobar; LA: La Argentina; CM: Cerro Mayor; E31: Escuela 31.

[Figura 4: Valores médios e desvio padrão (\% em massa) dos três principais componentes químicos da cerâmica da região: AF: Arroyo Fredes; An: Anahí; ME: Médanos de Escobar; LA: La Argentina; CM: Cerro Mayor; E31: Escuela 31.$]$
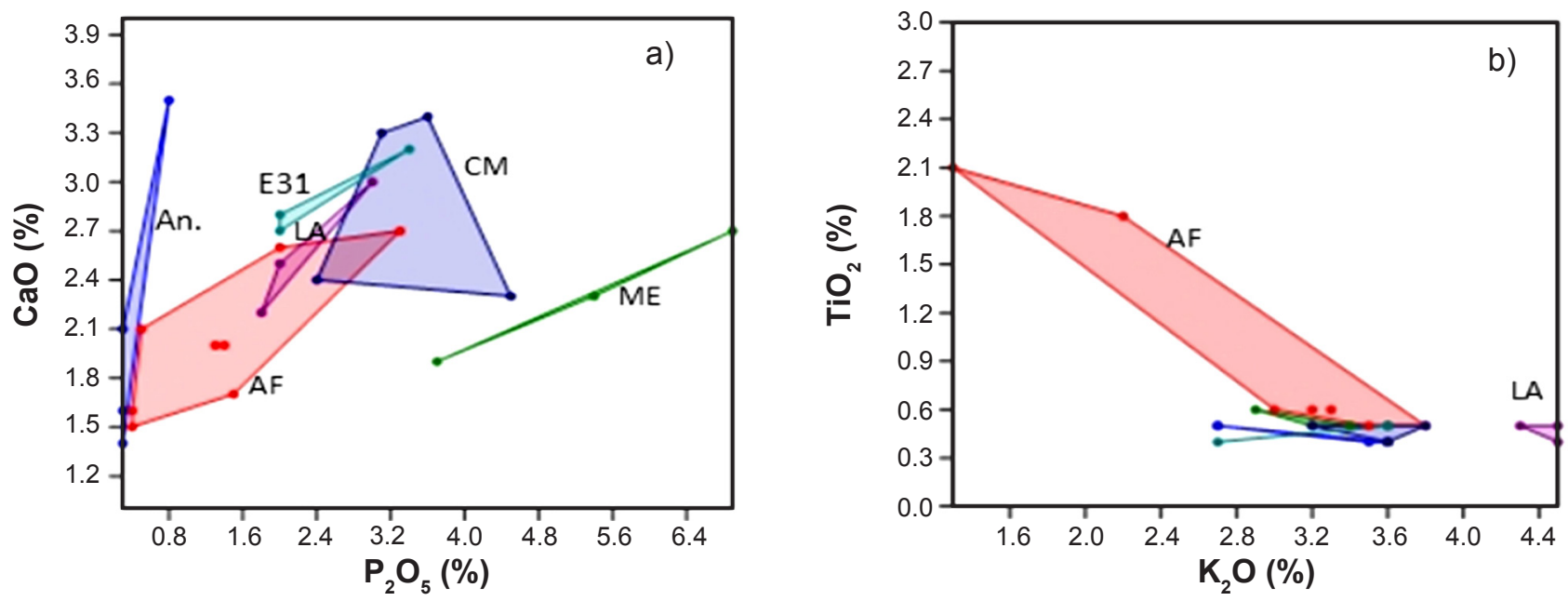

Figure 5. Biplots of oxide contents (wt \%): a) CaO- $\mathrm{P}_{2} \mathrm{O}_{5}$; and b) $\mathrm{TiO}_{2}-\mathrm{K}_{2} \mathrm{O}$. ME: Médanos de Escobar; AF: Arroyo Fredes; LA: La Argentina; An: Anahí; CM: Cerro Mayor; E31: Escuela 31.

[Figura 5: Biplots de teores de óxidos (wt\%): a) $\mathrm{CaO}-\mathrm{P}_{2} \mathrm{O}_{5}$; e b) $\mathrm{TiO}_{2}-\mathrm{K}_{2} \mathrm{O}$.]

components are listed in Table II. The chemical composition showed variation if the samples were considered as a single set. In fact, the two major components $\left(2 \% \mathrm{SiO}_{2}+\mathrm{Al}_{2} \mathrm{O}_{3}\right)$ varied between $76.1 \%$ and $56.0 \%(\bar{x}=66.6 \% \pm 3.9 \%)$. A smaller amount of iron oxide, ranging between $10.9 \%$ and $21.4 \%$ $(\bar{x}=14.6 \%)$, must be added to the main constituents, with a significant variation. Here pellets of iron oxide dispersed in the local clays are included, which, when cooked, harden and acquire reddish color, acting as natural tempers [8]. The inclusion of more or less of these small pellets of iron oxide in the analyzed samples was partly responsible for the observed variations, due to its punctuated distribution. These oxides have been identified in practically all the thin sections analyzed in the local pottery $[8,11,13]$. The X-ray images revealed their metallic composition [8], and recent studies with energy dispersive analysis of X-rays (EDAX) confirmed their composition (study in progress). These results reinforced the observations about the presence of pellets of iron oxide as natural tempers, that manifest themselves in the pottery

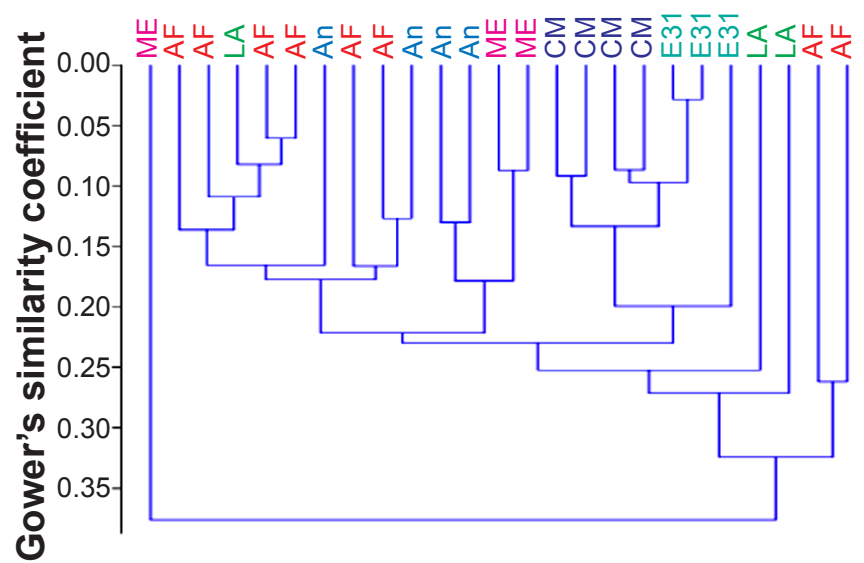

Figure 6: Cluster of the main components of the pottery using Gower's similarity coefficient. ME: Médanos de Escobar; AF: Arroyo Fredes; LA: La Argentina; An: Anahí; CM: Cerro Mayor; E31: Escuela 31.

[Figura 6: Cluster dos principais componentes da cerâmica usando coeficiente de similaridade de Gower.] 
as hardened red lumps $\left(\mathrm{Fe}^{3+}\right)$. It is feasible to consider that a small fraction of them, basically the black ones, includes $\mathrm{MnO}$ in their composition [8, 11, 14]. Manganese oxide, however, was in a much lower amount than iron oxide (Table II). The aforementioned main components $\left(\sum \% \mathrm{SiO}_{2}+\mathrm{Al}_{2} \mathrm{O}_{3}+\mathrm{Fe}_{2} \mathrm{O}_{3}\right)$ stood for approximately $80 \%$ of the composition of the fabrics.

Once the main chemical compositions were established, we analyzed, in particular, the variations of the observed elements. The $\mathrm{SiO}_{2}$, which was the main component, ranged from $61.5 \%$ (La Argentina) to the lowest value detected in Escuela 31, with only $43.3 \%$. The content of $\mathrm{Al}_{2} \mathrm{O}_{3}$ presented a lower range, being bounded between $17.6 \%$ (Anahí) and $12.6 \%$ (Cerro Mayor and La Argentina sites). In these two last sites, the contents of this oxide were particularly low, differing from the rest (Fig. 4). The $\mathrm{Fe}_{2} \mathrm{O}_{3}$, which was established as the third most important component, ranged from a minimum of $10.9 \%$ (La Argentina) to $21.4 \%$ as the maximum (Escuela 31, Fig. 4).

Table III - Trace-elements (in ppm) identified in analyzed sherds.

[Tabela III - Elementos-traço (em ppm) identificados nos fragmentos analisados.]

\begin{tabular}{|c|c|c|c|c|c|c|c|c|c|c|}
\hline Sample & $\mathrm{Rb}$ & $\mathrm{Sr}$ & $\mathrm{Y}$ & $\mathrm{Zr}$ & $\mathrm{Nb}$ & $\mathrm{Pb}$ & $\mathrm{V}$ & $\mathrm{Ni}$ & $\mathrm{Cu}$ & $\mathrm{Zn}$ \\
\hline \multicolumn{11}{|c|}{ Arroyo Fredes } \\
\hline 234001 & 196.5 & 273.3 & 54.2 & 171.5 & 19.8 & 50.0 & 171.4 & 54.8 & 58.3 & 183.7 \\
\hline 234002 & 148.4 & 307.6 & 48.7 & 154.2 & 20.4 & 50.4 & 167.9 & 59.0 & 56.4 & 159.0 \\
\hline 234003 & 116.4 & 257.1 & 66.7 & 223.2 & 29.2 & 28.5 & 582.6 & 67.2 & 105.2 & 175.8 \\
\hline 234004 & 50.8 & 230.7 & 62.1 & 267.8 & 35.3 & 27.9 & 655.1 & 64.4 & 158.8 & 154.5 \\
\hline 234005 & 171.7 & 291.4 & 49.6 & 124.5 & 16.5 & 56.1 & 166.2 & 55.3 & 48.6 & 157.9 \\
\hline 234006 & 155.9 & 538.4 & 52.8 & 179.4 & 21.0 & 47.7 & 196.0 & 64.4 & 65.7 & 206.9 \\
\hline 234007 & 117.0 & 200.5 & 48.2 & 161.0 & 19.8 & 49.5 & 207.9 & 65.5 & 52.0 & 157.1 \\
\hline 234000 & 130.7 & 209.5 & 49.6 & 165.7 & 19.7 & 54.2 & 194.3 & 62.8 & 40.5 & 161.5 \\
\hline $\mathrm{X}$ & 136 & 289 & 54 & 181 & 23 & 46 & 293 & 62 & 73 & 170 \\
\hline SD & 44 & 108 & 7 & 45 & 6 & 11 & 203 & 5 & 40 & 18 \\
\hline $\mathrm{CV}(\%)$ & 32.3 & 37.4 & 12.7 & 24.7 & 27.6 & 24.3 & 69.3 & 7.7 & 54.3 & 10.8 \\
\hline \multicolumn{11}{|c|}{ Anahí } \\
\hline 236001 & 108.9 & 241.7 & 41.0 & 173.9 & 16.1 & 48.2 & 168.6 & 51.7 & 63.6 & 148.3 \\
\hline 236002 & 130.3 & 412.8 & 48.8 & 218.3 & 15.2 & 61.8 & 169.4 & 60.6 & 106.4 & 138.3 \\
\hline 236003 & 176.6 & 218.0 & 44.7 & 105.3 & 14.0 & 40.7 & 155.4 & 54.9 & 55.8 & 206.1 \\
\hline 236000 & 173.4 & 223.1 & 44.2 & 104.6 & 13.9 & 48.8 & 152.6 & 56.5 & 65.4 & 193.2 \\
\hline $\mathrm{X}$ & 147 & 274 & 45 & 151 & 15 & 50 & 162 & 56 & 73 & 171 \\
\hline SD & 33 & 93 & 3 & 56 & 1 & 9 & 9 & 4 & 23 & 33 \\
\hline $\mathrm{CV}(\%)$ & 22.5 & 34.0 & 7.1 & 37.0 & 7.1 & 17.5 & 5.4 & 6.6 & 31.3 & 19.4 \\
\hline \multicolumn{11}{|c|}{ Médanos de Escobar } \\
\hline 233001 & 98.1 & 485.4 & 35.6 & 151.7 & 13.2 & 55.0 & 156.2 & 45.9 & 41.7 & 194.8 \\
\hline 233002 & 82.5 & 495.5 & 43.4 & 158.2 & 17.3 & 51.9 & 204.3 & 66.7 & 43.0 & 248.1 \\
\hline 233000 & 108.7 & 340.1 & 40.0 & 128.0 & 16.0 & 60.2 & 178.9 & 56.5 & 46.7 & 183.0 \\
\hline $\mathrm{X}$ & 96 & 440 & 40 & 146 & 16 & 56 & 180 & 56 & 44 & 209 \\
\hline SD & 13 & 87 & 4 & 16 & 2 & 4 & 24 & 10 & 3 & 35 \\
\hline $\mathrm{CV}(\%)$ & 13.6 & 19.7 & 9.8 & 10.9 & 13.6 & 7.5 & 13.4 & 18.5 & 5.9 & 16.6 \\
\hline \multicolumn{11}{|c|}{ La Argentina } \\
\hline 232001 & 149.3 & 487.9 & 47.7 & 153.1 & 18.4 & 44.9 & 166.2 & 52.5 & 69.7 & 129.1 \\
\hline 232003 & 147.8 & 705.3 & 46.3 & 218.1 & 20.1 & 40.4 & 162.5 & 53.2 & 45.5 & 131.8 \\
\hline 232000 & 153.0 & 457.7 & 47.6 & 151.5 & 17.1 & 48.5 & 154.0 & 55.1 & 56.9 & 133.6 \\
\hline $\mathrm{X}$ & 150 & 550 & 47.2 & 174 & 19 & 45 & 161 & 54 & 57 & 132 \\
\hline SD & 3 & 135 & 0.8 & 38 & 1 & 4 & 6 & 1 & 12 & 2 \\
\hline $\mathrm{CV}(\%)$ & 1.8 & 24.6 & 1.6 & 21.8 & 8.0 & 9.1 & 3.9 & 2.5 & 21.2 & 1.7 \\
\hline \multicolumn{11}{|c|}{ Cerro Mayor } \\
\hline 231002 & 84.8 & 404.4 & 39.7 & 192.4 & 13.2 & 32.2 & 132.4 & 61.5 & 48.8 & 129.2 \\
\hline 231003 & 91.8 & 226.2 & 35.7 & 166.5 & 12.5 & 37.3 & 149.9 & 50.4 & 65.4 & 131.6 \\
\hline 231007 & 86.2 & 389.0 & 36.5 & 269.1 & 15.2 & 31.7 & 138.3 & 52.1 & 38.2 & 116.2 \\
\hline 231000 & 82.5 & 451.7 & 31.6 & 221.9 & 13.3 & 24.6 & 151.0 & 53.3 & 58.3 & 122.8 \\
\hline X & 86 & 368 & 36 & 213 & 14 & 31 & 143 & 54 & 53 & 125 \\
\hline SD & 4 & 98 & 3 & 44 & 1 & 5 & 9 & 5 & 12 & 7 \\
\hline $\mathrm{CV}(\%)$ & 4.6 & 26.7 & 9.3 & 20.7 & 8.7 & 16.5 & 6.3 & 9.0 & 22.4 & 5.6 \\
\hline \multicolumn{11}{|c|}{ Escuela 31} \\
\hline 235001 & 107.7 & 270.5 & 46.7 & 233.7 & 15.2 & 45.4 & 163.4 & 60.3 & 56.1 & 125.0 \\
\hline 235002 & 97.1 & 263.5 & 31.0 & 99.5 & 11.7 & 62.8 & 162.6 & 45.1 & 46.8 & 103.6 \\
\hline 235000 & 105.1 & 262.0 & 44.0 & 229.6 & 15.0 & 47.2 & 153.5 & 54.7 & 48.0 & 133.6 \\
\hline$X$ & 104 & 265 & 41 & 188 & 14 & 52 & 160 & 53 & 50 & 121 \\
\hline $\mathrm{SD}$ & 6 & 5 & 8 & 76 & 2 & 10 & 6 & 8 & 5 & 15 \\
\hline $\mathrm{CV}(\%)$ & 5.4 & 1.7 & 20.8 & 40.7 & 13.8 & 18.6 & 3.4 & 14.4 & 10.1 & 12.8 \\
\hline
\end{tabular}




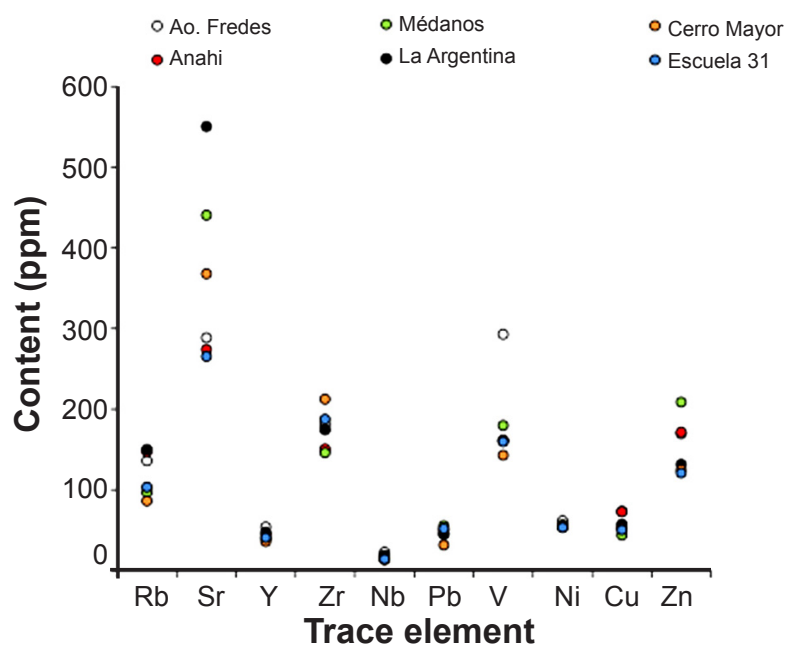

Figure 7: Trace-elements (average per site) detected in the sherds of this study.

[Figura 7: Elementos-traço (média por sítio) identificados nos fragmentos analisados.]
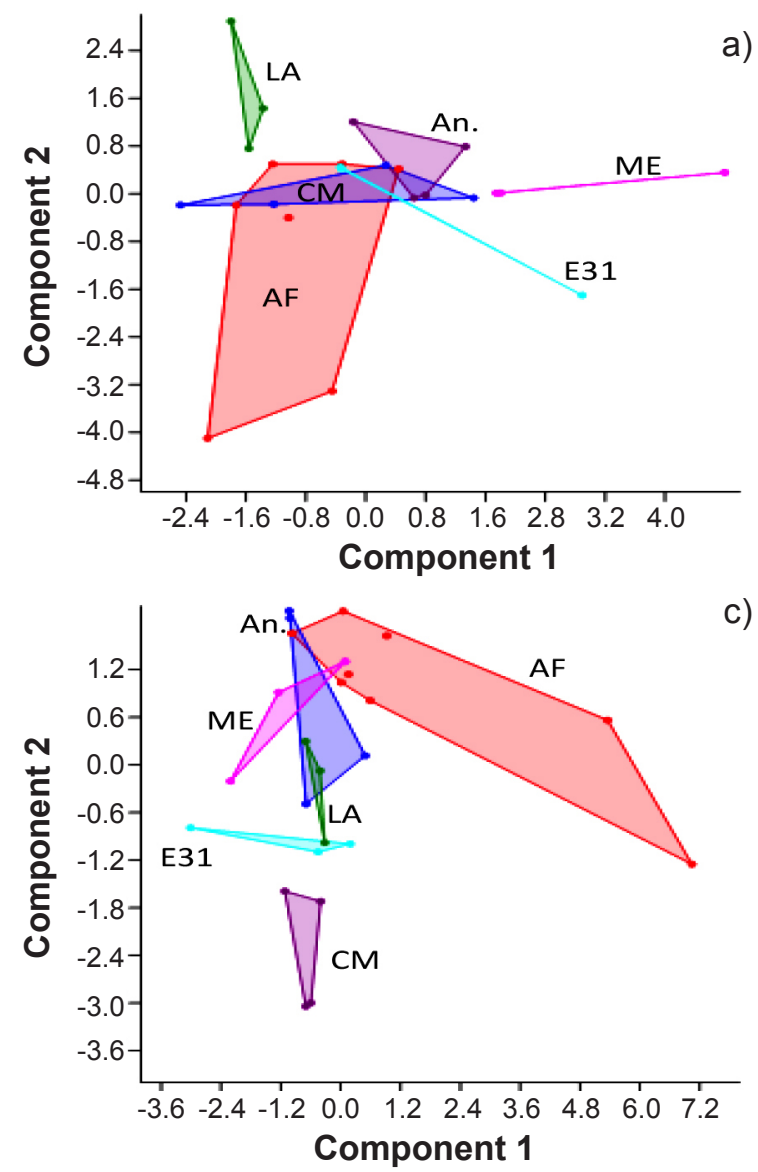

c)

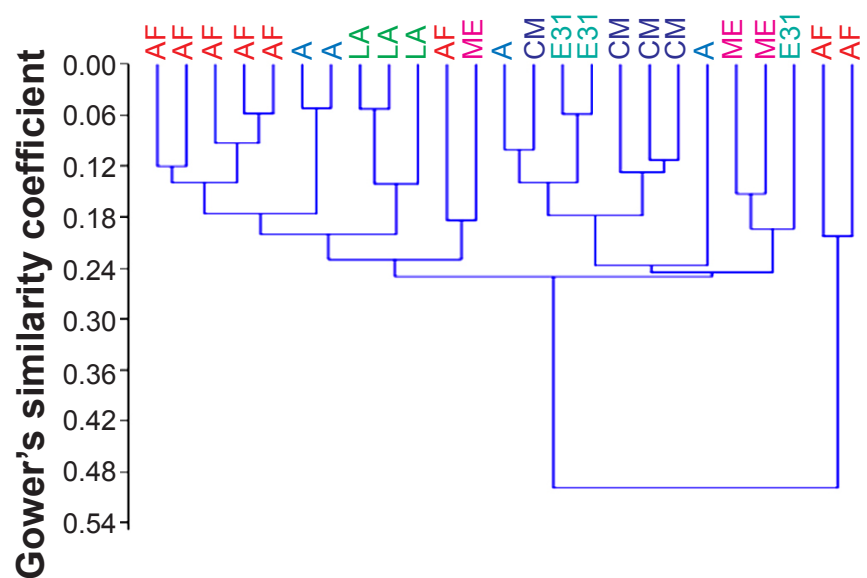

Figure 8: Cluster of trace-elements in the sherds using Gower's similarity coefficient. ME: Médanos de Escobar; AF: Arroyo Fredes; LA: La Argentina; An: Anahí; CM: Cerro Mayor; E31: Escuela 31.

[Figura 8: Cluster de elementos-traço dos fragmentos analisados através do coeficiente de similaridade de Gower.]
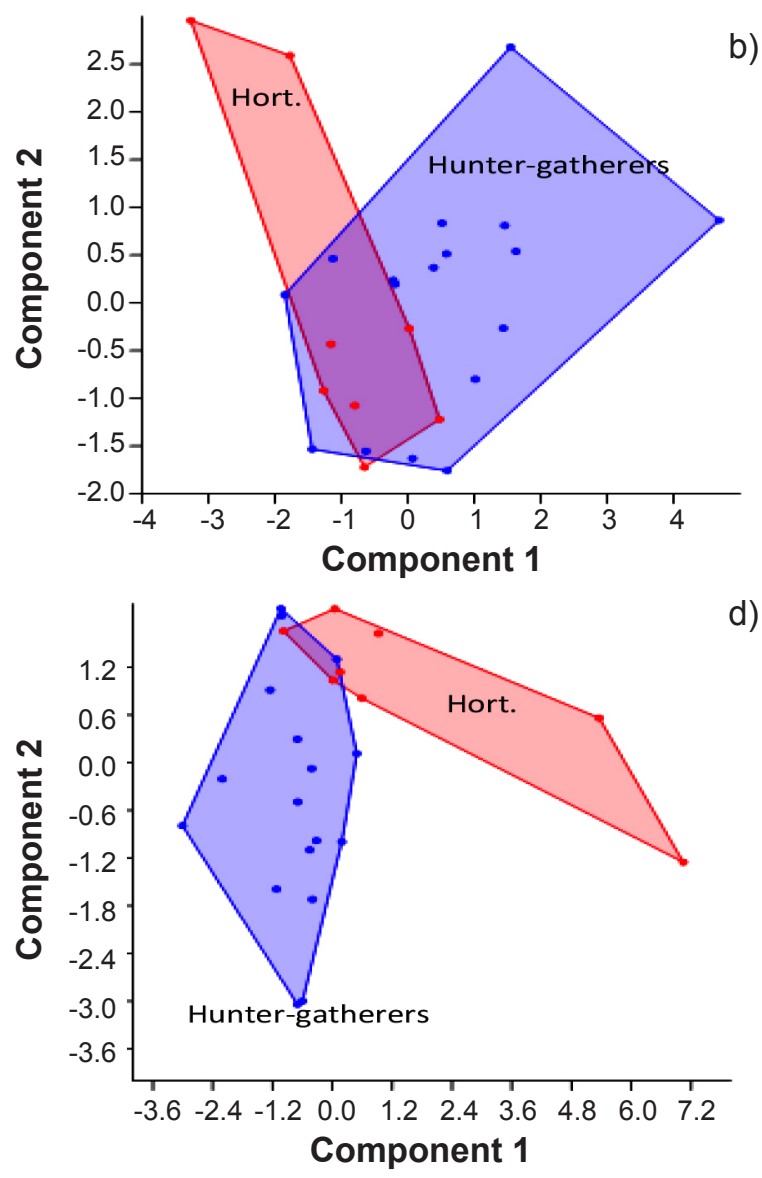

Figure 9: Correlation matrix (PCA) based on chemical composition of the major components (a,b) and trace-elements (c,d).

[Figura 9: Matriz de correlação (PCA) com base na composição química dos componentes principais $(a, b)$ e elementos-traço $(c, d)$.]

The other major components of the fabrics were present in low quantities. Some of them were only present in a site, as is the case of the $\mathrm{Na}_{2} \mathrm{O}$, which was only detected in
Arroyo Fredes (and in a single sample from La Argentina). The presence of this oxide in three samples and its absolute absence in others is certainly intriguing, which should be 
explored with new samples. The other variable component could correspond to a contamination of the sherds during their burial stage. Bones which were deposited together with the artifacts are usually the primary source for phosphorus $[15,16]$. However, the grouping that presented both the $\mathrm{CaO}$ and the $\mathrm{P}_{2} \mathrm{O}_{5}$ suggested that they were components of the clays and that they varied locally, or that they were added intentionally in some specific proportions depending on the site considered (Fig. 5). Finally, the $\mathrm{TiO}_{2}$ and $\mathrm{K}_{2} \mathrm{O}$ were present in similar quantities in all the samples except for those coming from La Argentina, but in any case, they discretely differed only in the $\mathrm{K}_{2} \mathrm{O}$ content. Very different was what happened with two of the Arroyo Fredes samples, which had substantially different contents in $\mathrm{TiO}_{2}$ and one also in $\mathrm{K}_{2} \mathrm{O}$ (Table II and Fig. 5).

A multivariate analysis was performed considering all the major elements. The results showed clusters according to the place of origin (Fig. 6). The Arroyo Fredes samples behaved in a dispersed manner, which reflected its internal variability. In the same way, a sample from La Argentina and another from Médanos de Escobar behaved dissimilar to the other samples from each respective site. It was not clear if this was due to more or less continuous variations of each site, where the small number of samples produced a dispersive effect, ungrouping some sherds, or if they represented pottery vessels manufactured in another sector of the wetland, or even if they responded to random issues of the analysis.

The results of the semiquantitative analysis of the traceelements are listed in Table III. The type and quantity of them were similar in the most of the samples, which were also clustered in relation to the locality from where they were recovered (Table III and Figs. 7 and 8). However, some specific trace-elements were not uniform, like the $\mathrm{Sr}$ in $\mathrm{La}$ Argentina, Cerro Mayor and Médanos de Escobar sites.

To conclude this study, in Fig. 9 we include two PCA (principal component analysis) of both major constituents and trace-elements. As can be seen, the samples from Arroyo Fredes partially shared the values of those recovered at hunter-gatherer sites, but with higher internal variability which was particularly represented in two specific sherds. These last two samples could correspond with the variability in the manufacture of the fabrics, or reflected the existence of pottery coming outside the region. In this sense, it is known that the Guaraní had an active exchange system based on fluvial mobility [10]. On the other hand, the values obtained in hunter-gatherer sites were grouped primarily according to each site, with scarce intrasite variability in general terms. This clearly reflected the local production of the pottery. The lower variability observed here does not imply not recognizing that the variation existed. Some part of this dispersion could be related to different manufacturing behaviors. To analyze whether these variations are part of a continuum or constitute discrete differences, it is essential to increase the current sampling levels in order to expand the database and to evaluate both the differences and the level of similarity within and between the groupings. In the same way, it is extremely useful to incorporate into this analysis those fragments that have been recognized in some sites that are clearly allochthonous, and that have been identified as such by their style, shape or type of fabric.

\section{CONCLUSIONS}

This study provided the first data related to the objective of this work, aimed at characterizing chemically the archaeological pottery vessels of the region. The results showed some variations which corresponded mainly to the specific sites from where they were recovered. These variations could be linked to differences in the clay banks and/or with different human behaviors. Either of these two options is considered, the pottery was local manufacture, at least for all the samples recovered at hunter-gatherer sites. We also observed that although this pottery shared the general chemical components with that manufactured by the horticultural groups, it had certain differences; some of them were due to the use of other tempers, but also, they could be due to different behaviors in the preparation of the fabric as well as the presence of extra-local pottery.

\section{ACKNOWLEDGMENT}

We wish to thank the two anonymous reviewers who improved the quality of the text.

\section{REFERENCES}

[1] M. Morgenstein, C.A. Redmount, J. Archaeol. Sci. 32 (2005) 1613.

[2] A.J. Nazaroff, K.M. Prufer, B.L. Drake, J. Archaeol. Sci. 37 (2010) 885.

[3] I. Nakai, S. Yamada, Y. Terada, Y. Shindo, T. Utaka, X-Ray Spectrom. 34 (2005) 46.

[4] M.S. Shackely, X-ray fluorescence spectrometry (XRF) in geoarchaeology, Springer, New York (2011) 7.

[5] J.K. Millhauser, E. Rodriguez-Alegria, M.D. Glascock, J. Archaeol. Sci. 38 (2011) 3141.

[6] D. Frankel, J.M. Webb, J. Archaeol. Sci. 39 (2012) 1380.

[7] Z.L. Epossi Ntah, R. Sobott, B. Fabbri, K. Bente, Cerâmica 63, 367 (2017) 413.

[8] D. Loponte, "Arqueología del humedal del Paraná inferior (Bajíos Ribereños meridionales)", Inst. Nac. Antropol. Pensam. Latinoam., Buenos Aires (2008) 410.

[9] D. Loponte, A. Acosta. Cadern. CEOM 29, 45 (2016) 125.

[10] D. Loponte, A. Acosta, Cuad. Inst. Nac. Ant. Pens. Latinoam. Ser. Espec. 1, 4 (2013) 193.

[11] M. Pérez, M.I, Capparelli, D. Loponte, T. Montenegro, T. Montenegro, N. Russo, Rev. Soc. Arqueol. Bras. 22, 1 (2009) 65.

[12] R.L. Santa Cruz, J.P. Bernal, Rev. Mexic. Cie. Geológ. 22, 3 (2005) 3294.

[13]. U. Camino, D. Scavelzon, A. Azkárate, D. Loponte, J.L. Solaum, A. Martínez, I. Sánchez, J.L. Cavallotto, Rev. 
Antropol. Mus. Entre Ríos, in press.

[14] F. Ottalagano, M. Pérez, Cuad. Instit. Nac. Antropol. Pens. Latinoam. S. Espec. 1, 2 (2013) 74.

[15] B. Fabbri, S. Gualtieri, Reasons of phosphorus pollution in archaeological pottery and its consequences: $a$ reassessment, Dev. Archaeol. Res. M.Adalslteinn T. Olander (Eds.), Nov. Sci. Publ., New York (2013) 41.

[16] C. Lemoine, M. Picon, Rev. d'Archéom. 6 (1982) 101. (Rec.07/09/2018, Rev.09/11/2018, 15/12/2018, 10/01/2019, Ac. 11/01/2019) 